\title{
Evaluation of an Enzyme Immunoassay for Hepatitis C Virus Antibody Detection Using a Recombinant Protein Derived from the Core Region of Hepatitis C Virus Genome
}

\author{
EPA Lopes, CH Granato*, V Lanzoni**, L Granero**, G Paranhos-Baccala***, \\ H Tomiyama*, AEB Silva, ML Ferraz/ ${ }^{+}$
}

\begin{abstract}
Disciplinas de Gastroenterologia *Doenças Infecciosas e Parasitária **Anatomia Patológica, Escola Paulista de Medicina, Universidade Federal de São Paulo, 04023-900 São Paulo, SP, Brasil ***Instituto BioMérieux, Lyon,

France
\end{abstract}

\begin{abstract}
This study was undertaken to evaluate an enzyme immunoassay (EIA) for hepatitis $C$ virus antibody detection (anti-HCV), using just one antigen. Anti-HCV EIA was designed to detect anti-HCV IgG using on the solid-phase a recombinant $C 22$ antigen localized at the $N$-terminal end of the core region of $H C V$ genome, produced by BioMérieux. The serum samples diluted in phosphate buffer saline were added to wells coated with the C22, and incubated. After washings, the wells were loaded with conjugated anti$I g G$, and read in a microtiter plate reader $(492 \mathrm{~nm})$. Serum samples of 145 patients were divided in two groups: a control group of 39 patients with non-C hepatitis (10 acute hepatitis $A, 10$ acute hepatitis $B$, 9 chronic hepatitis $B$, and 10 autoimmune hepatitis) and a study group consisting of 106 patients with chronic HCV hepatitis. In the study group all patients had anti-HCV detected by a commercially available EIA (Abbott $\left.{ }^{\circledR}\right)$, specific for HCV structural and nonstructural polypeptides, alanine aminotransferase elevation or positive serum HCV-RNA detected by nested-PCR. They also had a liver biopsy compatible with chronic hepatitis. The test was positive in 101 of the $106(95 \%)$ sera from patients in the study group and negative in 38 of the 39 (97\%) sera from those in the control group, showing an accuracy of $96 \%$. According to these results, our EIA could be used to detect anti-HCV in the serum of patients infected with hepatitis $C$ virus.
\end{abstract}

Key words: hepatitis C virus (HCV) - anti-HCV antibody - enzyme immunoassay

Chronic hepatitis $\mathrm{C}$ is a serious health problem worldwide (Hoofnagle 1997). Approximately half of the individuals with this infection became infected via the parenteral route mainly through blood transfusions or intravenous drug abuse (Alter 1995). After exposure, chronic liver disease occurs in at least $85 \%$ of patients, and $20 \%$ of these will eventually develop cirrhosis, with or without hepatocellular carcinoma (Seeff 1997).

Hepatitis $\mathrm{C}$ virus (HCV) genome is a positive sense RNA molecule, which encodes a polyprotein of around 3,000 amino acids. This protein is cleaved into the structural and non-structural peptides, which are used in diagnostic tests for antibodies against HCV (Bradley 1992). Soon after the

Research partially supported by Fapesp (no. 94/1072-2). EPA Lopes was recipient of a Capes-PICD fellowship. ${ }^{+}$Corresponding author. Fax: +55-11-572.5945. E-mail: Lucia@gastro.epm.br

Received 29 October 1999

Accepted 23 February 2000 virus was cloned in 1989, a diagnostic test for anti$\mathrm{HCV}$ was developed, using a single fusion nonstructural protein from the 5-1-1 region in an enzyme immunoassay (EIA) format (Kuo et al. 1989). However, this test had a limited sensitivity and a high frequency of false-positive results (Medina \& Schiff 1995).

A second-generation test was subsequently developed, including a structural protein (C22) in addition to the non-structural component and this led to an improvement in the sensitivity and specificity of the test (Medina \& Schiff 1995, Gretch 1997). More recently, a third-generation EIA has been produced including an antigen from a nonstructural region (NS5), but its true accuracy is still under evaluation (Medina \& Schiff 1995, Gretch 1997).

Although these newer tests, with structural and non-structural antigens, have improved the diagnostic accuracy of HCV infection, little has been described about an EIA using only a structural recombinant antigen. The aim of the current study was to evaluate an EIA for anti-HCV detection, using a structural recombinant antigen (C22) in the solid-phase as the target for anti-HCV detection. 


\section{PATIENTS AND METHODS}

Patients - Serum samples of 145 patients were divided in two groups: a control group of 39 patients with non-C hepatitis (10 acute hepatitis A, 10 acute hepatitis B, 9 chronic hepatitis B, and 10 autoimmune hepatitis) and a study group consisting of 106 patients with chronic HCV infection. Eighty-one (76\%) of the 106 patients were males and their median age was 34 (range: 18-69) years. Seventy-six $(72 \%)$ patients were white. Fifty-six $(53 \%)$ patients had a history of parenteral exposition and $40(38 \%)$ presented symptons. In the study group all patients had anti-HCV detected by a commercially available EIA (Abbott $\left.{ }^{\circledR}\right)$, and persistent alanine aminotransferase (ALT) elevation (more than six months) or a positive serum HCV-RNA. Persistent ALT elevation was detected in 100 (94\%) of the 106 patients and serum HCV-RNA was detected in $95(90 \%)$ patients. In addition, an inclusion criterion for the study group was that the patients should have had a liver biopsy compatible with chronic hepatitis. The histological preparations were submitted to semiquantitative analysis (grading of necroinflammatory activity and staging), as described by Desmet et al. (1994).

Methods - At the beginning of the study, serum samples anti-HCV were tested with a commercially available second-generation ELISA specific for HCV structural and nonstructural polypeptides, following the instructions of the suppliers (Abbott Laboratories, North Chicago, IL). NestedPCR, using primers targeted to the 5' untranslated region, as previously described by Shindo et al. (1991), detected HCV-RNA.

For patients in the control group, serum IgM anti-HAV, HBsAg, IgM and total anti-HBc were assayed using ELISA (Abbott Laboratories, North Chicago, IL). Autoantibodies (ANA and SMA) were tested using indirect immunofluorescence.

Anti-HCV EIA was designed to detect anti$\mathrm{HCV}$ core $\mathrm{IgG}$ using in the solid-phase only a recombinant $\mathrm{C} 22$ antigen produced by BioMérieux (Lyon, France). This antigen encodes the N-terminal 48 amino acids of the $\mathrm{HCV}$ core protein. All serum samples were stored at $-20^{\circ} \mathrm{C}$. In brief, the wells of microtiter plates (Hemobag $\left.{ }^{\circledR}\right)$ were coated overnight at $4^{\circ} \mathrm{C}$ with $100 \mu \mathrm{l}$ volume of $\mathrm{C} 22$ antigen $(5 \mu \mathrm{g} / \mathrm{ml})$ in carbonate buffer $(10 \mathrm{mM}, \mathrm{pH}$ 9.6). Thereafter, the wells were washed with phosphate buffer saline (PBS), containing 0.05\% Tween-20 (PBS/T) and blocked over-night at $4^{\circ} \mathrm{C}$ with 100 $\mu \mathrm{l}$ of human albumin in PBS (1\%). The plate was washed three times with PBS/T, and $100 \mu \mathrm{l}$ of serum diluted (1/100) in PBS containing 1\% albu$\min (\mathrm{pH} 7.2)$ were added and incubated at $37^{\circ}$ for $60 \mathrm{~min}$. The plate was washed a further three times with $\mathrm{PBS} / \mathrm{T}$, and $100 \mathrm{ml}$ of horseradish peroxidase goat anti-human $\operatorname{IgG}\left(\right.$ Sigma $\left.{ }^{\circledR}\right)$, diluted as serum samples (1/100), were added to each well. The plate was incubated for $60 \mathrm{~min}$ at $37^{\circ} \mathrm{C}$ and washed three more times with PBS/T. Then, $100 \mu$ l of o-phenylenediamine (in citrate buffer) was added to each well and incubated for $15 \mathrm{~min}$ at room temperature in the dark, with the reaction being stopped by the addition of $100 \mu \mathrm{l}$ of $\mathrm{H}_{2} \mathrm{SO}_{4}(1 \mathrm{~N})$. The color was read in a micro-titer plate reader at a wavelength of $492 \mathrm{~nm}$.

Sera from three healthy subjects and from three patients with chronic HCV hepatitis, which had previously been tested for anti-HCV antibodies by two commercial tests, were used as negative and positive controls. Test samples with an optic density (OD) greater than twice the mean absorbance of the three negative control sera were considered reactive for anti-HCV C22 IgG. The mean titer of anti-HCV IgG was considered the OD/cut-off ratio.

The local ethical committee approved this study. Results were compared using the Chi-square test, T-test, Fisher's exact test and Spearman rank correlation. A two-tailed $p$ value of less than 0.05 was considered statistically significant.

\section{RESULTS}

The assay was positive in 101 of 106 serum from patients in the study group and negative in 38 of 39 serum from patients in control group (Table I). Using the commercial assay as the goldstandard test, the new test had a sensitivity of $95 \%$ and a specificity of $97 \%$, positive and negative predictive values of $99 \%$ and $88 \%$, respectively, and an accuracy of $96 \%$.

Furthermore, our EIA was positive in 93 of 95 (98\%) patients who were HCV-RNA positive and negative in 3 of 11 (27\%) patients without viremia. Interestingly, the mean titers of OD/cut-off

\section{TABLE I}

Results of the enzyme immunoassay (EIA) in 145 patients with hepatitis in relation to a commercial assay (Abbott $($ )

\begin{tabular}{lrcr}
\hline & \multicolumn{2}{c}{ ELISA second-generation (Abbott $\AA)$} & Total \\
\cline { 2 - 3 } & Positive & Negative & 102 \\
\hline positive & 101 & 1 & 43 \\
$\begin{array}{l}\text { EIA negative } \\
\text { Total }\end{array}$ & 5 & 38 & 145 \\
\hline
\end{tabular}

Sensitivity $=95 \%$; specificity $=97 \%$; positive predictive value $=99 \%$; negative predictive value $=88 \%$ 
value for the EIA from serum samples of 95 patients positive for HCV-RNA (OD/cut-off $=3.47$ $\pm 1.12)$ were significantly higher $(p=0.001)$ than HCV-RNA negative of 11 patients $(\mathrm{OD} /$ cut-off $=$ $2.27 \pm 1.29)$, (Figure). We did not find any correlation ( $p=\mathrm{NS}$ ) between the mean titers of OD/cutoff for the EIA and histological activity, using Spearman rank correlation (Table II).

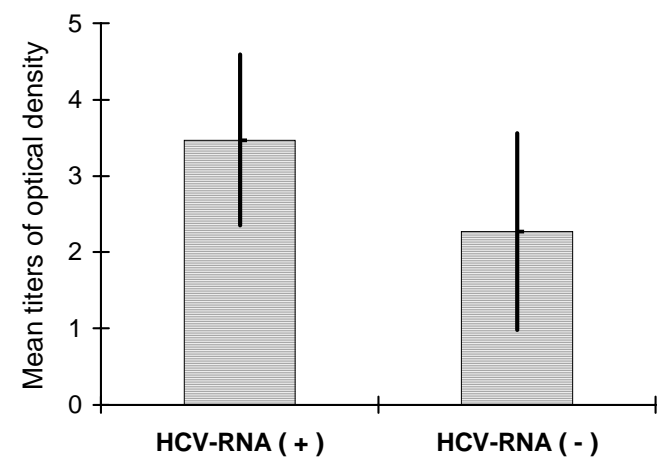

The mean titers of optic density/cut-off for the enzyme immunoassay from serum samples of 106 patients, 95 positive and 11 negative for RNA of hepatitis $\mathrm{C}$ virus (HCV). The difference is statistically significant $(\mathrm{p}=0.001)$.

\section{TABLE II}

Correlation between the mean titers of optic density/ cut-off for the enzyme immunoassay in relation to histological grading and staging $(p=\mathrm{NS})$

\begin{tabular}{lccccc}
\hline Histological & \multicolumn{5}{c}{ Numerical grading and staging system } \\
\cline { 2 - 6 } & 0 & 1 & 2 & 3 & 4 \\
\hline Peatures & 1,7 & 3,6 & 3,3 & 3,5 & 3,4 \\
Portal activity & 2,9 & 3,2 & 3,6 & 3,0 & - \\
Staging activity & 3,2 & 3,4 & 3,3 & 3,5 & 3,3 \\
\hline
\end{tabular}

\section{DISCUSSION}

Since 1989, the sequence analysis of the HCVgenome has allowed the production of assays with synthetic peptides and recombinant antigens for anti-HCV detection. Following the confirmation of the limited accuracy of the first-generation tests, which incorporated only non-structural antigens, a series of immunoassays have been developed. These new tests, incorporating one structural synthetic peptide or more than two proteins, including one from the structural region, had proven to be more accurate (Medina \& Schiff 1995, Gretch 1997). However, few studies have been published using only one structural recombinant antigen.
Katayama et al. (1992), using only one synthetic peptide (p22) derived from the structural region of $\mathrm{HCV}$, found that the assay had more accuracy than first-generation tests for the diagnosis of $\mathrm{HCV}$ infection in the acute phase and for blood screening. A possible explanation for these results is that a structural antibody would appear much earlier and more persistently than antibodies against the non-structural region of HCV. Manzini et al. (1993), using one structural synthetic peptide for anti-HCV detection, found a highly significant correlation between this test and two commercial available immunoassays of first and second-generation.

More recently, Trowbridge et al. (1996), evaluating an assay using only one recombinant antigen (C22) in the solid-phase, tested 453 serum samples submitted for routine anti-HCV screening and compared it with a third-generation EIA (Ortho®). They found a significant correlation between these two tests and only four samples showed discordant results. Using just one structural recombinant antigen (C22), we also found a significant correlation between our EIA and a commercial second-generation assay (Abbott $\AA$ ). In addition, we found a direct correlation between the mean titers of OD/cut-off using EIA and viraemia, detected by nested-PCR, although the number of HCV-RNA negative samples was small.

Trowbridge et al. (1996) also described a significant correlation between the anti-HCV core titers and viraemia. Furthermore, Chen et al. (1995), using an anti-HCV core assay, also found a correlation between the titers of anti-HCV core $\mathrm{IgG}$ and the serum levels of HCV-RNA, detected by a competitive PCR. These results suggest that patients with high titers of anti-HCV core are most likely to be viraemic, but further studies with a larger numbers of patients are necessary to confirm these findings. Thus, the use of the OD titers by anti-HCV core test may be a helpful alternative to PCR, particularly in places where this test is not widely available.

In this study, we did not find a correlation between the mean titers of OD/cut-off for the EIA and histological activity, as was also not found by Shindo et al. (1995). However, these same authors found a direct correlation between the mean titers of anti-HCV and HCV-RNA levels in liver tissue (Shindo et al. 1995).

According to our results, this "in house" EIA is comparable in terms of accuracy to a commercial second-generation assay. It is an easy test to perform and appears to be less expensive than commercially available assays for the diagnosis of hepatitis $\mathrm{C}$ virus infection. In addition, it is important that these findings could be confirmed more widely, using the EIA for serum-epidemiological surveys. 


\section{REFERENCES}

Alter MJ 1995. Epidemiology of hepatitis C in the west. Semin Liver Dis 15: 5-14.

Bradley DW 1992. Virology, molecular biology, and serology of hepatitis C virus. Transf Med Rev 6: 93102.

Chen M, Sönnerborg A, Sällberg M 1995. Levels of hepatitis $\mathrm{C}$ virus (HCV) RNA in serum and their relationship to levels of immunoglobulin $\mathrm{M}$ and $\mathrm{G}$ antibodies against $\mathrm{HCV}$ core protein. J Clin Microbiol 33: 778-780.

Desmet VJ, Gerber M, Hoofnagle JH, Manns M, Scheuer P 1994. Classification of chronic hepatitis: diagnosis, grading and staging. Hepatology 19: 1513-1520.

Gretch DR 1997. Diagnosis tests for hepatitis C. Hepatology 26 (Suppl.1): 43S-47S.

Hoofnagle JH 1997. Hepatitis C: the clinical spectrum of disease. Hepatology 26 (Suppl. 1): 15S-20S.

Katayama T, Mazda T, Kikuchi S, Harada S, Matsuura Y, Chiba J, Ohba H, Saito I, Miyamura T 1992. Improved serodiagnosis of non-A, non-B hepatitis by an assay detecting antibody to hepatitis $C$ virus core antigen. Hepatology 15: 391-394.

Kuo G, Choo Q-L, Alter HG, Gitnick GI, Redeker AG, Purcell RH, Miyamura T, Dienstag JL, Alter MJ, Stevens CE, Tegtmeier GE, Bonino F, Colombo M, Lee WS, Kuo C, Berger K, Shuster JR, Overby LR,
Bradley DW, Houghton M 1989. An assay for circulating antibodies to a major etiologic virus of human non-A, non-B hepatitis. Science 244: 362-364.

Manzini P, Calvo PL, Brunetto MR, Baldi M, Abate ML, Oliveri F, Negro F, Balzola F, Saracco G, Verme G, Chiba J, Miyamura T, Bonino F 1993. Clinical significance of the antibody to the putative core protein of hepatitis $\mathrm{C}$ virus in patients with chronic liver disease. Liver 13: 222-226.

Medina M, Schiff ER 1995. Hepatitis C: diagnosis assays. Semin Liver Dis 15: 33-40.

Seeff LB 1997. Natural history of hepatitis C. Hepatology 26 (Suppl. 1): 21S-28S.

Shindo M, Arai K, Sokawa Y, Okuno T 1995. The virological and histological states of anti-hepatitis $\mathrm{C}$ virus-positive subjects with normal liver biochemical values. Hepatology 22: 418-425.

Shindo M, Di Bisceglie AM, Cheung L, Shih JWK, Cristiano K, Feinstone SM, Hoofnagle JH 1991. Decrease in hepatitis C viral RNA during alpha interferon therapy for chronic hepatitis C. Ann Intern Med 115: 700-704.

Trowbridge R, Sloots TP, Buda P, Faoagali J, Hyland C, Young I. Gowans EJ 1996. An ELISA for the detection of antibody to the core antigen of hepatitis $\mathrm{C}$ virus: use in diagnosis and analysis of indeterminate samples. J Hepatol 24: 532-538. 